\title{
QUALITY OF SILAGE PRODUCED FROM INTERCROPPED CORN RR AND SOYBEANS RR
}

\author{
QUALIDADE DE SILAGEM PRODUZIDA A PARTIR DE MILHO RR \\ CONSORCIADO COM SOJA RR
}

\author{
Isabella Sichierski CARDOSO ${ }^{1}$; Adriano JAKELAITIS ${ }^{\text {* }}$; Karolyna Oliveira MARQUES $^{1}$; \\ Katia Cylene GUIMARÃES ${ }^{1}$; Leandro Spíndola PEREIRA ${ }^{1}$ \\ 1. Instituto Federal de Educação, Ciência e Tecnologia Goiano, Campus Rio Verde, Rio Verde, GO, Brasil. isabellacardoso- \\ rv@hotmail.com; adriano.jakelaitis@ifgoiano.edu.br*
}

\begin{abstract}
The objective of this study was to produce silage from intercropped RR glyphosate tolerant corn (RR - Roundup Ready) and RR soybeans under Brazilian Cerrado conditions. The research was carried out in off-season between February and June 2015, in Rio Verde, Goiás (Brazil). In the experimental period the rainfall was $865 \mathrm{~mm}$ and the average temperature of $23.7^{\circ} \mathrm{C}$. Two trials were performed. The first had corn rows spaced in $1 \mathrm{~m}$ with a row of soybeans in the interrow. The second had double corn rows interspersed with one row of soybeans, all spaced in $0.50 \mathrm{~m}$. In both trials, we used a randomized block design, in a $2 \times 2+3$ factorial scheme, with four replications. Primary factor consisted of two types of pre-sowing fertilization: one only in corn rows and the other over the total area. The secondary factor corresponded to two soybean varieties: medium and late cycle variety. In addition, three control treatments were made: one of corn and two of soybeans. The corn cutoff point was at the hard farinaceous stage when the milk line reaches half the grain, and in the sole crop soybean at the R5.5 final phase of grain filling. Silage was stored in PVC experimental silos for 60 days. The intercropped treatments, in both spatial arrangements, promoted increases in neutral detergent fiber and acid detergent fiber contents. Soybean monoculture presented high values of crude protein and ethereal extract. There were higher effluent losses in medium-cycle soybean variety silage when it was grown in single cropping. However, the lowest effluent losses were recorded for silages of medium-cycle soybean intercropped under a double row pre-sowing corn fertilization system. The soybeans mixed silages produced together with corn under off-season conditions did not yield satisfactory results.
\end{abstract}

KEYWORDS: Genetically modified crops. Zea mays. Glycine max.

\section{INTRODUCTION}

Corn stands out as a standard crop for silage production (REZENDE et al., 2010; HASSANAT et al., 2013). However, corn silage has low protein content, limiting its exclusive use for high productivity animals. The soybeans are also an advantageous alternative for silage production at lower costs. If associated with a forage grass, soybean use can increase silage crude protein content in about 4.0 to $18 \%$, depending on the forage species and its harvest point (GOBETTI et al., 2011).

The advantages of ensiling corn and soybeans rely on the production of a mixed forage with equivalent, or even higher, quality compared to single cropping (DEMIREL et al., 2009). Besides, it may promote higher contents of crude protein and high nutritive value without concerns in dry matter digestibility, as well as maintain $\mathrm{pH}$ and ammoniacal nitrogen at suitable levels without interfering with fermentation profile
(EVANGELISTA et al., 1991). According to these authors, such mix would contribute to the forage consumption and, consequently, increase animal production. In addition to this, intercropping brings benefits such as an improved exploitation of area, sunlight, and nutrients, besides the easiness to harvest the material (GEREN et al., 2008). Nonetheless, there is little research on corn-soybean intercropping for Brazilian conditions, mainly related to new cultural arrangements, and mixing proportions.

One measure used in intercropping between grasses and soybeans is interspersing rows of each crop, or even bands, enabling several cultural arrangements (UNDIE et al., 2012; CRUSCIOL et al., 2012). Studies in this area have been carried out with sorghum intercropped with soybeans (SANTOS et al., 2009; REZENDE et al., 2010). Regrettably, this practice has not been adopted in an extensive way due to issues related to mechanization, increasing costs, and cultural practices, mainly regarding weed control. 
Conversely, with the advent of genetically modified glyphosate-resistant soybean and corn plants (Roundup Ready - RR), new possibilities for optimization of this management system arise. In this sense, questions related to population arrangement, fertilization management, and used plant varieties are currently the object of research and technology transfer. In this context, the aim of this study was to adjust the intercropping between $\mathrm{RR}$ corn and RR soybean for spatial arrangement, soybean variety, and pre-sowing fertilization in order to produce a silage of high quality.

\section{MATERIAL AND METHODS}

The study was carried out between February and June of 2015, in the Research Center for Agriculture - Fazenda Retiro Cambaúbas (farm), in Rio Verde, Goiás (Brazil). The farm is located at the geographical coordinates: $17^{\circ} 47^{\prime} \mathrm{S}$ latitude, $51^{\circ} 0^{\prime}$ W longitude and $777 \mathrm{~m}$ altitude.

Two trials were conducted simultaneously. Trial 1 consisted of corn rows spaced in $1 \mathrm{~m}(6$ plants $\left.\mathrm{m}^{-1}\right)$ and one soybean row in interrow $(25$ plants $\mathrm{m}^{-1}$ ). Trial 2 was composed of double rows of corn (4.5 plants $\left.\mathrm{m}^{-1}\right)$ interspersed with one of the soybeans $\left(25\right.$ plants $\left.\mathrm{m}^{-1}\right)$, with all rows were spaced in $0.50 \mathrm{~m}$.

Corn hybrid 30F53YHR (Pioneer) was used adopting a plant population of 60,000 plants $\mathrm{ha}^{-1}$. Sowing was made in the second half of February 2015. Pre-sowing fertilization in all plots consisted of $100 \mathrm{~kg} \mathrm{ha}^{-1} \mathrm{P}_{2} \mathrm{O}_{5}, 70 \mathrm{~kg} \mathrm{ha}^{-1} \mathrm{~K}_{2} \mathrm{O}$ and $20 \mathrm{~kg} \mathrm{ha}^{-1}$ $\mathrm{N}$. Topdressing for single cropped and intercropped corn was made by applying $150 \mathrm{~kg} \mathrm{ha}^{-1} \mathrm{~N}$ along the rows, at V4-5. Soybean varieties were previously inoculated with Bradyrhizobium spp. and treated with Crop Star ${ }^{\mathbb{B}}$, following the manufacturer's recommendation. Weed control was performed with glyphosate $\left(720 \mathrm{~g} \mathrm{ha}^{-1}\right)$ at 15 and 30 days after emergence (DAE) of corn.

Both experiments were conducted in a randomized block design with treatments arranged in a $2 \times 2+3$ factorial scheme, with four replications. The first factor consisted of two types of pre-sowing fertilization, one applying fertilizer only along corn rows (CF) and another over the total area (CSF). The second factor corresponded to two varieties of soybeans, one medium-cycle variety (MC) (BRSGO 6959RR) and one late-cycle variety (LC) (NA7337RR). Soybean and corn monocultures (controls) were additional treatments.
The corn harvest point was defined at hard farinaceous stage when the milk line reaches half the grain, at the 96 days after the emergence (DAE), and for single cropped soybeans at the R5.5 stage, at the 50 DAE to BRSGO 6959RR and 59 DAE to NA7337RR. After harvest, silage was stored in experimental silos made of PVC and with a dimension of $0.4 \mathrm{~m}$ in length and $0.1 \mathrm{~m}$ in diameter. Soybean and corn samples, from all treatments, were chopped into $2 \mathrm{~cm}$ mean size particles, being placed in the silos in compacted layers of $10 \mathrm{~cm}$.

The silos were closed, sealed, and stored for 60 days. After fermentation, they were opened and the material removed and homogenized. From each silo, a 500-g aliquot per replication was set aside and taken to a forced ventilation oven $\pm 55^{\circ} \mathrm{C}$ by 72 hours for dry matter measurements. After drying, these samples were ground in Willey mills for further bromatological analysis. The variables assessed were ethereal extract (EE), neutral detergent fiber (NDF), acid detergent fiber (ADF), lignin (LIG), crude protein (CP), effluent and gas losses (EGL), in vitro dry matter digestibility (IVDMD) and $\mathrm{pH}$, according to procedures described by Silva and Queiroz (2002). Effluent (EL) and gaseous (GL) losses were analyzed according to the Jobim et al., (2007) methodology.

The collected data underwent analysis of variance and means compared by the Dunnett's and Tukey's tests, when necessary. Pearson correlation estimates were obtained for the variables. The adopted error rate was 5\%. The statistical analyses were performed using ASSISTAT software 7.7-beta version (SILVA et al., 2016).

\section{RESULTS AND DISCUSSION}

\section{Intercropping between corn and soybean in a single-row arrangement}

Regarding bromatological analyses, we noted that $\mathrm{ADF}$ of silage from $\mathrm{CF}$ treatments showed better results, however, not differing from comparative control (Table 1). This outcome corroborates that of Eichelberger et al. (1997) who observed that soybean insertion in corn silage promoted ADF increase. Nevertheless, here we observed that such increase was only reached for mixed silages from treatments under CF system, what was not observed for the other system, as expected since soybeans were also inserted. 
Table 1. Acid detergent fiber (ADF), neutral detergent fiber (NDF), lignin (LIG), crude protein (CP), ether extract (EE), and in vitro dry matter digestibility (IV-DMD) of silage from intercropped soybean and corn and from monocultures (Trial 1), as function of the treatments: CSF - total area pre-sowing fertilization; $\mathrm{CF}$ - corn row pre-sowing fertilization; $\mathrm{MC}$ - medium-cycle soybean variety; LC - latecycle soybean variety.

\begin{tabular}{|c|c|c|c|c|}
\hline Treatment & $\mathrm{MC}$ & $\mathrm{LC}$ & Average & CV (\%) \\
\hline \multicolumn{5}{|l|}{ ADF (\%) } \\
\hline $\mathrm{CSF}$ & 10.52 & 13.37 & $11.94 \mathrm{~b}$ & \multirow{5}{*}{15.16} \\
\hline $\mathrm{CF}$ & 15.19 & 15.30 & $15.25 \mathrm{a}$ & \\
\hline Average & 12.86 & 14.33 & & \\
\hline $\mathrm{SM}^{1 /}$ & 13.82 & 12.64 & & \\
\hline $\mathrm{CM}^{2 /}$ & 14.45 & & & \\
\hline \multicolumn{5}{|l|}{ NDF (\%) } \\
\hline $\mathrm{CSF}$ & 80.64 & 79.21 & 79.92 & \multirow{5}{*}{4.32} \\
\hline $\mathrm{CF}$ & 76.38 & 75.13 & 75.75 & \\
\hline Average & 78.51 & 77.17 & & \\
\hline $\mathrm{SM}$ & 80.47 & $81.85^{+}$ & & \\
\hline $\mathrm{CM}$ & 75.95 & & & \\
\hline \multicolumn{5}{|l|}{ LIG (\%) } \\
\hline CSF & 5.35 & 8.20 & 6.78 & \multirow{5}{*}{24.59} \\
\hline $\mathrm{CF}$ & 7.97 & 5.53 & 6.75 & \\
\hline Average & 6.66 & 6.87 & & \\
\hline $\mathrm{SM}$ & 7.25 & 6.05 & & \\
\hline $\mathrm{CM}$ & 5.16 & & & \\
\hline \multicolumn{5}{|l|}{ CP (\%) } \\
\hline $\mathrm{CSF}$ & $9.12^{-}$ & 9.77 & 9.45 & \multirow{5}{*}{11.66} \\
\hline $\mathrm{CF}$ & 9.59 & 9.36 & 9.47 & \\
\hline Average & 9.35 & 9.57 & & \\
\hline $\mathrm{SM}$ & $20.67^{+}$ & $22.21^{+}$ & & \\
\hline $\mathrm{CM}$ & 10.75 & & & \\
\hline \multicolumn{5}{|l|}{ EE (\%) } \\
\hline CSF & $3.89^{\circ} \mathrm{aA}$ & $4.45 \mathrm{aA}$ & 4.17 & \multirow{5}{*}{33.44} \\
\hline $\mathrm{CF}$ & $4.40 \mathrm{aA}$ & $3.41 \mathrm{bB}$ & 3.91 & \\
\hline Average & 4.15 & 3.93 & & \\
\hline $\mathrm{SM}$ & $9.86^{+}$ & $11.62^{+}$ & & \\
\hline $\mathrm{CM}$ & 5.94 & & & \\
\hline \multicolumn{5}{|c|}{ IV-DMD (\%) } \\
\hline CSF & 76.90 & 66.54 & 71.72 & \multirow{5}{*}{8.22} \\
\hline $\mathrm{CF}$ & 70.90 & 61.15 & 66.05 & \\
\hline Average & 73.90 & 63.84 & & \\
\hline $\mathrm{SM}$ & 62.45 & 63.59 & & \\
\hline $\mathrm{CM}$ & 64.80 & & & \\
\hline
\end{tabular}

1/SM - soybean monoculture. 2/CM - corn monoculture. + or - stand for superior and inferior, respectively, compared to the control $(\mathrm{CM})$ by the Dunnett's test $(\mathrm{p}<0.05)$. Means followed by different lowercase letters within columns and uppercase letters within lines are statistically different by the Tukey's test $(\mathrm{p}<0.05)$. Trial 1 - Intercropping between corn and soybean in a single-row arrangement.

Statistical differences were found regarding NDF content only for the comparative control, in which LC soybean monoculture had a higher value (Table 1). NDF values found here were superior to those encountered in other studies (LEONEL et al., 2008; COSTA, 2011), which ranged from 47 to $64 \%$. For LIG, there was no difference among treatments (Table 1), being a result different from that found by other authors, such as Van Soest (1994). This author found superior values for this variable in silages from leguminous plants when compared to grasses. Despite the lack of differences among treatments, values found for single cropped soybean silage approached those found by Rigueira et al. (2015), who reported an average LIG of 5.1. Concerning mixed silages, values found here varied little in relation to those found by Leonel et al. (2008). These authors reported LIG average contents from 6.59 and $6.75 \%$ when intercropping brachiaria grass with soybeans.

Only soybean monocultures showed a higher CP content than that found in corn monoculture (Table 1). These results are similar to those obtained by Lempp et al. (2000), who found 
no difference for intercropped treatments in a single-row arrangement and for monocultures. The low CP levels in treatments with soybean insertion can be attributed to the low amount of leaves during the harvest for ensiling since the highest $\mathrm{CP}$ contents are in the leaves.

For EE, there was an interaction between the factors. Intercropping with LC soybeans under CF system was inferior to the other treatments for both factors (Table 1). Soybean monocultures were superior to the control while intercropping of $\mathrm{MC}$ soybeans under CSF arrangement and LC soybeans under CF were inferior. This higher content of EE in single cropped soybean silages corroborate the values found by Rigueira et al. (2015), which are around $9 \%$.

Through Table 1, one can note that no statistical difference was found for IV-DMD. Such result corroborates the statement of Evangelista et al. (1991), who claimed there was no increment by insertion of soybeans in silage. Even though Even though no statistically significant difference was found, IV-DMD contents in single cropped soybean silages tended to decrease. This fact can be explained by the high EE content found, with values above $8 \%$ EE, which may directly interfere with digestibility (VAN SOEST, 1994), as well as the increase in LIG contents that can increase ADF, affecting thus digestibility.

Tables 2 and 3 present the proportions of morphological components of soybeans and corn plants found in the silage mass, respectively. When comparing all treatments with the control of $\mathrm{MC}$ soybean monoculture, we may infer that all treatments presented smaller proportions of leaf and stem in relation to the comparative control. For pods, intercropped treatments reached lower proportions in the same comparison; yet, LC soybean monoculture was superior. Although most of the treatments had a lower number of pods in relation to the control, all of them were superior to those found by Gobetti et al. (2011), which averaged $35 \%$.

Table 2. Proportion of leaves, stems, and pods of soybeans intercropped with corn and in monoculture (Trial 1), within silage mass as function of the treatments: CSF - total area pre-sowing fertilization; CF corn row pre-sowing fertilization; MC - medium-cycle soybean variety; LC - late-cycle soybean variety.

\begin{tabular}{|c|c|c|c|}
\hline \multirow{2}{*}{ Treatment } & \multicolumn{3}{|l|}{ Leaf } \\
\hline & $\mathrm{MC}$ & $\mathrm{LC}$ & Average \\
\hline CSF & $0.00^{-}$ & $0.00^{-}$ & 0.00 \\
\hline $\mathrm{CF}$ & $0.00^{-}$ & $0.00^{-}$ & 0.00 \\
\hline Average & 0.00 & 0.00 & \\
\hline $\mathrm{SM}^{1}$ & 0.184 & $0.051^{-}$ & \\
\hline CV (\%) & 73.69 & & \\
\hline \multirow{2}{*}{ Treatment } & Stem & & \\
\hline & $\mathrm{MC}$ & $\mathrm{LC}$ & Average \\
\hline CSF & $0.015^{-}$ & $0.012^{-}$ & 0.013 \\
\hline $\mathrm{CF}$ & $0.018^{-}$ & $0.008^{-}$ & 0.013 \\
\hline Average & 0.016 & 0.010 & \\
\hline $\mathrm{SM}^{1}$ & 0.217 & $0.174^{-}$ & \\
\hline CV (\%) & 7.88 & & \\
\hline \multirow{2}{*}{ Treatment } & Pod & & \\
\hline & $\mathrm{MC}$ & $\mathrm{LC}$ & Average \\
\hline CSF & $0.055^{-}$ & $0.041^{-}$ & 0.048 \\
\hline $\mathrm{CF}$ & $0.077^{-}$ & $0.036^{-}$ & 0.056 \\
\hline Average & 0.066 & 0.038 & \\
\hline $\mathrm{SM}^{1}$ & 0.599 & $0.774^{+}$ & \\
\hline CV $(\%)$ & 10.34 & & \\
\hline
\end{tabular}

1/SM - soybean monoculture. + or - stand for superior and inferior, respectively, compared to the control (CM) by the Dunnett's test $(\mathrm{p}<0.05)$. Trial 1 - Intercropping between corn and soybean in a single-row arrangement. 
Table 3. Proportion of leaves, stems, straw, kernels, and corncob of corn plants intercropped with different soybean varieties (MC and LC) and in monoculture (Trial 1), within silage mass, as function of the treatments: CSF - total area pre-sowing fertilization; $\mathrm{CF}$ - corn row pre-sowing fertilization; $\mathrm{MC}$ medium-cycle soybean variety; $\mathrm{LC}$ - late-cycle soybean variety.

\begin{tabular}{lllllll}
\hline \multirow{2}{*}{ Treatment } & Leaf & \multicolumn{5}{c}{ Stem } \\
\cline { 2 - 7 } & MC & LC & Average & MC & LC & Average \\
\hline CSF & 0.192 & 0.207 & 0.199 & 0.177 & 0.202 & 0.189 \\
CF & 0.227 & 0.186 & 0.206 & 0.212 & 0.173 & 0.192 \\
Average & 0.209 & 0.196 & & 0.194 & 0.187 & \\
CM $^{1}$ & 0.216 & & & 0.212 & & \\
CV $(\%)$ & 11.38 & & & 10.43 & &
\end{tabular}

\begin{tabular}{lllllll}
\hline \multirow{2}{*}{ Treatment } & Straw & \multicolumn{5}{c}{ Grains } \\
\cline { 2 - 7 } & MC & LC & Average & MC & LC & Average \\
\hline CSF & 0.078 & 0.084 & 0.081 & $0.403 \mathrm{aA}$ & $0.370 \mathrm{bA}$ & 0.386 \\
CF & 0.081 & 0.083 & 0.082 & $0.304 \mathrm{bA}$ & $0.432 \mathrm{aA}$ & 0.368 \\
Average & 0.079 & 0.083 & & 0.353 & 0.401 & \\
CM & 0.086 & & & 0.403 & & \\
CV $(\%)$ & 11.38 & & & 6.54 & &
\end{tabular}

\begin{tabular}{llll}
\hline \multirow{2}{*}{ Treatment } & \multicolumn{2}{l}{ Corncob } & \\
\cline { 2 - 4 } & MC & LC & Average \\
\hline CSF & 0.082 & 0.079 & 0.080 \\
CF & 0.084 & 0.080 & 0.082 \\
Average & 0.083 & 0.079 & \\
CM & 0.080 & & \\
CV (\%) & 8.14 & & \\
\hline
\end{tabular}

1/CM - corn monoculture. + or -stand for superior and inferior, respectively, compared to the control (CM) by the Dunnett's test $(\mathrm{p}<0.05)$. Means followed by different lowercase letters within columns and uppercase letters within lines are statistically different by the Tukey's test $(\mathrm{p}<0.05)$. Trial 1 - Intercropping between corn and soybean in a single-row arrangement.

For corn, the only variable to show significant differences was the kernel. The treatment with MC soybean under CF fertilization had a lower participation in silage composition if compared to the control. However, if considering soybean varieties, both $\mathrm{MC}$ under $\mathrm{CF}$ and $\mathrm{LC}$ under CSF showed lower proportions of corn kernels (Table 3).

Despite no statistical differences, proportional values found for leaves, on average $20.25 \%$, were higher than those reported by Zopollatto et al. (2009), when studying different corn cultivars for silage production, finding values between 11.4 and $15.4 \%$.

In a different way, stem proportion found here was well below, on average $19.05 \%$, than the one found by Costa et al. (2000). These authors also evaluated different cultivars of corn for silage and obtained proportional values between 38.7 and
$46.7 \%$. Notwithstanding, our results were near those reported by Thomas et al. (2001), which ranged from 23.2 to $25.8 \%$. Such outcome can be attributed to corn planting densities given the spatial arrangement adopted. The proportion of kernels found was above those observed by Zopollatto et al. (2009), which found a maximum of $36.6 \%$. Conversely, for corncobs, the proportions found were similar to the same study, being from 7.1 to $10.5 \%$

It was noticed that the linear correlations between soybean and corn morphological components and variables of silage bromatological quality highlight a negative correlation $(-0,504 *)$ between EE and corn kernel proportion in the silage, since larger amounts of corn kernels can reduce the amount of oil in the silage. 
Table 4 describes the silage losses by effluent and by gases, as well as its $\mathrm{pH}$. Regarding losses by effluents, only MC soybean monoculture showed higher values compared to corn monoculture. It has occurred due to high moisture in soybeans during ensiling, besides a greater compaction applied, which directly influenced the amount of effluent produced (GEBREHANNA et al., 2014).

Regarding losses by gases, there was no significant difference among treatments. The results for gas losses were much higher than were those found by Lopes et al. (2014) in soybean silage, which ranged from 7.39 to 9.76 . For $\mathrm{pH}$, soybean monocultures presented values significantly higher than the control, while intercropping of $\mathrm{MC}$ soybeans and under $\mathrm{CF}$ system was statistically lower, but all treatments, except soybean monocultures, showed $\mathrm{pH}$ levels within the ideal range (3.8 to 4.2). Lempp et al. (2000) pointed out that soybeans have interference with lactic fermentation, except in silage using single cropped soybeans, where $\mathrm{pH}$ is much higher. However, values still lower than those found by Dias et al. (2010), who reported an average $\mathrm{pH}$ of 5.3 for soybean silages.

Table 4. Losses by effluent, losses by gases and $\mathrm{pH}$ of silage from intercropping of soybean and corn and monocultures (Trial 1), as function of the treatments: CSF - total area pre-sowing fertilization; CF corn row pre-sowing fertilization; MC - medium-cycle soybean variety; LC - late-cycle soybean variety.

\begin{tabular}{lllll}
\hline Treatment & MC & LC & Average & CV (\%) \\
\hline Losses by effluent & & & & \\
CSF & 0.792 & 0.857 & 0.825 & \\
CF & 0.700 & 0.662 & 0.681 & \\
Average & 0.746 & 0.760 & & \\
SM $^{1 /}$ & $1.747^{+}$ & 0.840 & & \\
CM $^{2 /}$ & 1.112 & & 0.569 & \\
\hline Losses by gases & & 0.495 & 0.582 & \\
CSF & 0.642 & 0.612 & & \\
CF & 0.552 & 0.554 & & \\
Average & 0.597 & & 3.95 & \\
SM & 0.570 & & 3.91 & \\
CM & 0.760 & 3.95 & & \\
pH & & 3.93 & & \\
CSF & 3.95 & 3.94 & & \\
CF & $3.89^{-}$ & & & \\
Average & 3.92 & $4.59^{+}$ & & \\
MS & 3.97 & & & \\
CM & & & & \\
\hline
\end{tabular}

1/SM - soybean monoculture. 2/CM - corn monoculture. + or -stand for superior and inferior, respectively, compared to the control $(\mathrm{CM})$ by the Dunnett's test $(\mathrm{p}<0.05)$. Trial 1 - Intercropping between corn and soybean in a single-row arrangement.

\section{Intercropping between corn and soybean in a double-row arrangement}

In this type of arrangement, results regarding ADF, lignin, and IV-DMD were not statistically different among treatments (Table 5). Gomide et al. (1987) reported similar values for ADF in silages composed by soybeans intercropped with regular corn, dwarf corn, fodder sorghum, and grain sorghum. LIG contents in single cropped soybean silage were smaller than those found by Dias et al. (2010), who claimed levels between 10.7 to $12.9 \%$. As for mixed silage, the values were quite varied and, as in the single-row arrangement test, were not similar to those found by Leonel et al. (2008).
The lack of difference among treatments regarding IV-DMD corroborates findings of Evangelista et al. (1991). For NDF and CP, both soybean monocultures showed the highest rates for these variables, if compared to the control (Table 5). For NDF, as in the single-row arrangement trial, the values registered in our study were superior to those found in other studies (LEONEL et al., 2008; COSTA, 2011). It can be accounted as a favorable factor since this variable is related to rumination stimulus. The results concerning $\mathrm{CP}$ are similar to those reported by Lempp et al. (2000); they stated that greater amounts of soybeans in mixed silages promote higher contents of $\mathrm{CP}$, but not enough to establish a statistical difference with silages composed only of corn. 
Table 5. Acid detergent fiber (ADF), neutral detergent fiber (NDF), lignin (LIG), crude protein (CP), ether extract (EE), and in vitro dry matter digestibility (IV-DMD) of silage from intercropping of soybean and corn and monocultures (Trial 2), as function of the treatments: CSF - total area pre-sowing fertilization; $\mathrm{CF}$ - corn row pre-sowing fertilization; $\mathrm{MC}$ - medium-cycle soybean variety; LC - latecycle soybean variety.

\begin{tabular}{|c|c|c|c|c|}
\hline Treatment & $\mathrm{MC}$ & $\mathrm{LC}$ & Average & $\mathrm{CV}(\%)$ \\
\hline \multicolumn{5}{|l|}{ ADF (\%) } \\
\hline $\mathrm{CSF}$ & 14.76 & 18.56 & 16.66 & \multirow{5}{*}{28.69} \\
\hline $\mathrm{CF}$ & 15.26 & 13.78 & 14.52 & \\
\hline Average & 15.01 & 16.17 & & \\
\hline $\mathrm{SM}^{1 /}$ & 13.29 & 13.21 & & \\
\hline $\mathrm{CM}^{2 /}$ & 15.90 & & & \\
\hline \multicolumn{5}{|l|}{ NDF (\%) } \\
\hline $\mathrm{CSF}$ & 78.53 & 70.07 & 74.30 & \multirow{5}{*}{8.06} \\
\hline $\mathrm{CF}$ & 73.15 & 79.77 & 76.46 & \\
\hline Average & 75.84 & 74.92 & & \\
\hline $\mathrm{SM}$ & $81.98^{+}$ & $81.93^{+}$ & & \\
\hline $\mathrm{CM}$ & 72.88 & & & \\
\hline \multicolumn{5}{|l|}{ LIG (\%) } \\
\hline CSF & 5.55 & 5.19 & 5.37 & \multirow{5}{*}{57.01} \\
\hline $\mathrm{CF}$ & 6.54 & 9.41 & 7.97 & \\
\hline Average & 6.04 & 7.29 & & \\
\hline $\mathrm{SM}$ & 7.89 & 7.83 & & \\
\hline $\mathrm{CM}$ & 5.79 & & & \\
\hline \multicolumn{5}{|l|}{ CP (\%) } \\
\hline $\mathrm{CSF}$ & 9.06 & 9.48 & 9.27 & \multirow{5}{*}{9.25} \\
\hline $\mathrm{CF}$ & 9.98 & 10.23 & 10.11 & \\
\hline Average & 9.52 & 9.86 & & \\
\hline SM & $22.03^{+}$ & $22.00^{+}$ & & \\
\hline $\mathrm{CM}$ & 8.56 & & & \\
\hline \multicolumn{5}{|l|}{ EE (\%) } \\
\hline $\mathrm{CSF}$ & $4.10 \mathrm{aA}$ & $4.10 \mathrm{aA}$ & 4.10 & \multirow{5}{*}{13.15} \\
\hline $\mathrm{CF}$ & $4.30^{+} \mathrm{aA}$ & $3.28 \mathrm{bB}$ & 3.79 & \\
\hline Average & 4.20 & 3.69 & & \\
\hline $\mathrm{SM}$ & $9.86^{+}$ & $11.62^{+}$ & & \\
\hline $\mathrm{CM}$ & 3.65 & & & \\
\hline \multicolumn{5}{|c|}{ IV-DMD (\%) } \\
\hline CSF & 63.43 & 71.11 & 67.27 & \multirow{5}{*}{6.23} \\
\hline $\mathrm{CF}$ & 71.68 & 69.96 & 70.82 & \\
\hline Average & 67.55 & 70.53 & & \\
\hline $\mathrm{SM}$ & 62.70 & 69.50 & & \\
\hline $\mathrm{CM}$ & 72.21 & & & \\
\hline
\end{tabular}

1/SM - soybean monoculture. 2/CM - corn monoculture. + or - + or - stand for superior and inferior, respectively, compared to the control $(\mathrm{CM})$ by the Dunnett's test $(\mathrm{p}<0.05)$. Means followed by different lowercase letters within columns and uppercase letters within lines are statistically different by the Tukey's test $(\mathrm{p}<0.05)$. Trial 2 - Intercropping between corn and soybean in a double-row arrangement.

An interaction between the evaluated factors was observed regarding the content of EE. Either for soybean variety or fertilization system, the lowest rates of $\mathrm{EE}$ were observed for intercropped LC soybeans under CSF system (Table 5). If compared to single cropped corn, both soybean monocultures and intercropping with $\mathrm{MC}$ soybeans under $\mathrm{CF}$ were superior. These findings show once again a direct relationship between soybean presence and EE contents, as already reported by Rigueira et al. (2015).
Tables 6 and 7 shows the proportions of soybean and corn morphological components in the ensiled mass, respectively. For soybean components, all treatments obtained a lower proportion of leaves, stem, and pod in comparison with MC soybean control, except for LC soybean monoculture, which was significantly higher than the control. If compared with the single-row arrangement test, the proportions of soybean components were much lower. Moreover, in most of the treatments, pods, which are of major importance 
for silage, presented lower values than those obtained by Gobetti et al. (2011).

Table 6. Proportions of soybean leaves, stems, and pods in the silage mass from soybeans intercropped with corn and in single cropping (Trial 2) as function of the treatments: CSF - total area pre-sowing fertilization; $\mathrm{CF}$ - corn row pre-sowing fertilization; $\mathrm{MC}$ - medium-cycle soybean variety; LC - latecycle soybean variety.

\begin{tabular}{llll}
\hline & Leaf & & \\
\cline { 2 - 4 } Treatment & MC & LC & 0.00 \\
CSF & $0.00^{-}$ & $0.00^{-}$ & 0.00 \\
CF & $0.00^{-}$ & $0.00^{-}$ & \\
Average & 0.00 & 0.00 & \\
SM $^{1}$ & 0.188 & $0.018^{-}$ & \\
CV $(\%)$ & 35.04 & &
\end{tabular}

\begin{tabular}{llll}
\hline & Stem & & Average \\
\cline { 2 - 4 } Treatment & MC & LC & 0.009 \\
CSF & $0.012^{-}$ & $0.006^{-}$ & 0.008 \\
CF & $0.011^{-}$ & $0.006^{-}$ & \\
Average & 0.011 & 0.006 & \\
SM & 0.230 & $0.180^{-}$ & \\
CV $(\%)$ & 16.67 &
\end{tabular}

\begin{tabular}{llll}
\hline & Pod & & \\
\cline { 2 - 4 } Treatment & MC & LC & Average \\
\hline CSF & $0.049^{-}$ & $0.022^{-}$ & 0.035 \\
CF & $0.041^{-}$ & $0.022^{-}$ & 0.031 \\
Average & 0.045 & $0.022^{-}$ & \\
SM & 0.582 & $0.802^{+}$ & \\
CV $(\%)$ & 6.20 & & \\
\hline
\end{tabular}

1/SM - soybean monoculture. + or -stand for superior and inferior, respectively, compared to the control (CM) by the Dunnett's test $(\mathrm{p}<0.05)$. Trial 2 - Intercropping between corn and soybean in a double-row arrangement.

Table 7. Proportions of corn leaves, stem, straw, kernels, and corncobs in the silage mass from corn intercropped with soybeans and in single cropping (Trial 2) as function of the treatments: CSF - total area pre-sowing fertilization; $\mathrm{CF}$ - corn row pre-sowing fertilization; $\mathrm{MC}$ - medium-cycle soybean variety; LC - late-cycle soybean variety.

\begin{tabular}{|c|c|c|c|c|c|c|}
\hline \multirow{2}{*}{ Treatment } & \multicolumn{3}{|l|}{ Leaf } & \multicolumn{3}{|l|}{ Stem } \\
\hline & $\mathrm{MC}$ & $\mathrm{LC}$ & Average & $\mathrm{MC}$ & $\mathrm{LC}$ & Average \\
\hline $\mathrm{CSF}$ & 0.232 & 0.211 & 0.221 & 0.211 & 0.200 & 0.205 \\
\hline $\mathrm{CF}$ & 0.214 & 0.222 & 0.216 & 0.192 & 0.205 & 0.198 \\
\hline Average & 0.223 & 0.216 & & 0.201 & 0.202 & \\
\hline $\mathrm{CM}^{1}$ & 0.231 & & & 0.211 & & \\
\hline CV (\%) & 9.83 & & & 17.20 & & \\
\hline \multirow{2}{*}{ Treatment } & \multicolumn{3}{|l|}{ Straw } & \multicolumn{3}{|c|}{ Kernels } \\
\hline & $\mathrm{MC}$ & $\mathrm{LC}$ & Average & $\mathrm{MC}$ & $\mathrm{LC}$ & Average \\
\hline $\mathrm{CSF}$ & 0.085 & 0.090 & 0.087 & 0.338 & 0.392 & 0.365 \\
\hline $\mathrm{CF}$ & 0.083 & 0.092 & 0.087 & 0.358 & 0.369 & 0.363 \\
\hline
\end{tabular}




\begin{tabular}{|c|c|c|c|}
\hline Average & 0.084 & 0.091 & 0.348 \\
\hline $\mathrm{CM}$ & 0.082 & & 0.397 \\
\hline CV (\%) & 17.64 & & 13.95 \\
\hline
\end{tabular}

\begin{tabular}{llll}
\hline \multirow{2}{*}{ Treatment } & \multicolumn{2}{l}{ Corncob } & \\
\cline { 2 - 4 } & MC & LC & Average \\
\hline CSF & 0.084 & 0.085 & 0.084 \\
CF & 0.077 & 0.084 & 0.080 \\
Average & 0.080 & 0.084 & \\
CM & 0.077 & & \\
CV $(\%)$ & 8.01 & & \\
\hline
\end{tabular}

1/CM - corn monoculture. Trial 2 - Intercropping between corn and soybean in a double-row arrangement.

For corn (Table 7), it can be noted that there was no effect of the treatments on the proportion of morphological components in the ensiled mass. On the other hand, corncob values are in agreement with those found by Zopollatto et al. (2009). These authors reported percentages of 7.1 to $10.5 \%$ corncobs for corn at the ensiling point; in our study, these values were between 7.7 and $8.5 \%$. Likewise, our results for corn kernels, between 33.8 and $39.2 \%$, corroborate those of Zopollatto et al. (2009), who reported a variation from 32.4 to $36.6 \%$ at corn ensiling point.

For corn leaves and stem, our results were similar to those of Jaremtchuk et al. (2005), who adopted the same corn harvest point; they reported variations of 21.7 to $30.9 \%$ for leaves and from 18.1 to $24.9 \%$ for stem, while here these ranges were from 21.1 to $23.2 \%$ and 19.2 to $21.1 \%$ for leaves and stem, respectively. There was no the linear correlations between the proportions and variables of silage bromatological quality.

Table 8 describes the values of effluent losses, gas losses, and $\mathrm{pH}$. Regarding effluent loss, the treatment presenting the lowest values was the one composed by intercropped MC soybeans under CF system; whereas the highest losses were recorded in MC soybeans in monoculture. These high values of losses by effluents of MC soybean monoculture are related to the high humidity of the material at the time of ensiling. If compared to materials with higher dry matter contents, a negative relationship was observed between dry matter content and effluent volume (GEBREHANNA et al., 2014).

Table 8. Losses by effluent, losses by gases and $\mathrm{pH}$ of silage from intercropping of soybean and corn and monocultures (Trial 2), as function of the treatments: CSF - total area pre-sowing fertilization; CF corn row pre-sowing fertilization; MC - medium-cycle soybean variety; LC - late-cycle soybean variety.

\begin{tabular}{lllll}
\hline Treatment & MC & LC & Average & CV (\%) \\
\hline Losses by effluents & & & & \\
CSF & $0.787 \mathrm{aA}$ & $0.935 \mathrm{aA}$ & 0.861 & \\
CF & $0.407 \mathrm{bB}$ & $0.927 \mathrm{aA}$ & 0.667 & \\
Average & 0.597 & 0.931 & & \\
$\mathrm{SM}^{1 /}$ & $2.075^{+}$ & 0.857 & \\
$\mathrm{CM}^{2 /}$ & 1.010 & & & \\
Losses by gases & & & 0.661 \\
CSF & 0.675 & 0.647 & 0.822 & \\
CF & 0.810 & 0.835 & & \\
Average & 0.742 & 0.741 &
\end{tabular}




\begin{tabular}{lllll}
\hline $\mathrm{pH}$ & & & & \\
$\mathrm{CSF}$ & $3.97^{+}$ & 3.95 & 3.96 & \\
$\mathrm{CF}$ & $3.96^{+}$ & 3.94 & 3.95 & 0.93 \\
Average & 3.96 & 3.94 & & \\
$\mathrm{SM}$ & $4.75^{+}$ & $4.45^{+}$ & \\
$\mathrm{CM}$ & 3.88 & &
\end{tabular}

1/SM - soybean monoculture. 2/CM - corn monoculture. + or -stand for superior and inferior, respectively, compared to the control $(\mathrm{CM})$ by the Dunnett's test $(\mathrm{p}<0.05)$. Means followed by different lowercase letters within columns and uppercase letters within lines are statistically different by the Tukey's test $(\mathrm{p}<0.05)$. Trial 2 - Intercropping between corn and soybean in a double-row arrangement.

Treatments had no statistical difference for gas losses, however, all of them showed high values, which might have been due to an alcohol production (ethanol or mannitol). Conversely, for $\mathrm{pH}$, soybean monocultures and intercropping treatments involving $\mathrm{MC}$ soybean were the ones with the highest values. This outcome is similar to that obtained by Barbosa et al. (2011), who observed higher $\mathrm{pH}$ values for mixed silages of corn and soybeans, as well as even higher values for soybean silage alone. This increase and high value, especially in single cropped soybean silage, is justified by increases in buffering capacity occur because of higher percentages of CP in soybeans. In spite of having a higher $\mathrm{pH}$ than the other treatments, soybean silages still presented lower values for this variable whether compared with the results of Paula et al. (2009), who found a value of 5.54 for this type of silage.

\section{CONCLUSIONS}

Soybeans intercropped with corn increases the neutral detergent fiber and acid detergent fiber contents in silage.
Soybean silages have high values of crude protein and ether extract, but when intercropped with corn, these variables have no increase in silage.

There is little correlation between morphological components and bromatological variables of the silage. Soybean silage presented higher $\mathrm{pH}$ values; moreover, medium-cycle soybean variety (MC), in the double-row arrangement, also had this index increased.

The largest losses by effluent were observed for silage from medium-cycle soybean variety. Yet the lowest losses by effluent were recorded for silages from intercropping mediumcycle soybean variety under a corn row pre-sowing fertilization (CF) system, in the double-row arrangement.

We may conclude that inserting soybeans to produce off-season silages with corn had no satisfactory results.

\section{ACKNOWLEDGEMENTS}

The authors want to thank the National Council for Scientific and Technological Development (CNPq) for financial support.

RESUMO: Objetivou-se neste trabalho adequar o sistema de consórcio entre milho com tolerância ao herbicida glifosato (RR - Roundup Ready) e soja RR para obtenção de silagem de qualidade em condições do Cerrado brasileiro. A pesquisa foi conduzida na safrinha entre fevereiro e junho de 2015, em Rio Verde, Goiás (Brasil). A pluviosidade do período experimental foi de $865 \mathrm{~mm}$ e a temperatura média de $23,7^{\circ} \mathrm{C}$. Realizou-se dois ensaios, adequando formas de adubação de semeadura, arranjo de plantas e cultivares. Utilizou-se delineamento em blocos casualizados, em fatorial $2 \times 2+3$, com quatro repetições, sendo o fator primário duas modalidades de adubação de semeadura na linha: somente no milho, e em área total; o fator secundário correspondeu a duas variedades de soja: ciclo médio e tardio; mais três testemunhas: uma de milho e duas de soja. O ponto de corte do milho foi no estádio farináceo duro quando a linha do leite atinge metade do grão, e na soja em monocultivo no estádio fenológico R5.5, fase final de enchimento de grãos. Armazenou-se a silagem em silos experimentais de PVC por 60 dias. Os tratamentos de consórcio em ambos os arranjos aumentaram os teores de fibra em detergente neutro e fibra em detergente ácido. Os monocultivos de soja obtiveram valores elevados de proteína bruta e extrato etéreo. Ocorreu maior perda por efluente na silagem da variedade de soja de ciclo médio cultivada em monocultivo. No entanto, as menores perdas por efluente foram registradas para silagens de culturas de soja de ciclo médio consorciadas sob um sistema de fertilização pré- 
semeadura de linha de milho, no arranjo de linha dupla. A inserção de soja para produzir silagens mista juntamente com o milho em condições de safrinha não teve resultados satisfatórios.

PALAVRAS-CHAVES: Culturas geneticamente modificadas. Zea mays. Glycine max.

\section{REFERENCES}

BARBOSA, L. A.; REZENDE, A. V.; RABELO, C. H. S.; RABELO, F. H. S.; NOGUEIRA, D. A.

Estabilidade aeróbia de silagens de milho e soja exclusivas ou associadas. Ars Veterinária, Jaboticabal, v. 27, n. 4, p. 255-262, 2011. Disponível em: http://arsveterinaria.org.br/index.php/ars/article/viewFile/393/376.

Acesso em: 07 jul. 2016.

COSTA, P. M. Consórcio capim-braquiária, milho e leguminosas: produtividade, qualidade das silagens e desempenho animal. 2011. 57 f. Dissertação (Mestrado em Zootecnia) - Curso de Pós-Graduação em Zootecnia, Universidade Federal dos Vales do Jequitinhonha e Mucuri, Diamantina, 2011.

COSTA, R. S.; RODRIGUES, J. A. S.; GONCALVES, L. C.; RODRIGUES, N. M.; BORGES, I.; BORGES, A. L. C. C.; SALIBA, E.; JUNIOR, R. G. Características agronômicas de doze cultivares de milho para silagem. In: REUNIÃO ANUAL DA SOCIEDADE BRASILEIRA DE ZOOTECNIA, 37., 2000, Viçosa, Anais... Viçosa: SBZ, 2000, p. 1-3. Disponível em:

https://ainfo.cnptia.embrapa.br/digital/bitstream/item/45170/1/Caracteristicas-agronomicas-4.pdf Acesso em: 10 set. 2017.

CRUSCIOL, C. A. C.; MATEUS, G. P.; NASCENTE, A. S. MARTINS, P. O.; BORGHI, E.; PARIZ, C. M. An innovative crop-forage intercrop system: early cycle soybean cultivars and palisadegrass. Agronomy Journal, Madison, v. 104, n. 4, p. 1085-1095, 2012. Disponível em: https://doi.org/10.2134/agronj2012.0002. Acesso em: 10 set. 2017.

DEMIREL, M.; CELIK, S.; TEMUR, C.; GUNEY, M.; CELIK, S. Determination of fermentation properties and digestibility characteristics of combination of corn-soybean and corn silages. Journal of Animal and Veterinary Advances, Faisalabad, v. 8, n. 4, p. 711-714, 2009. Disponível em: http://www.medwelljournals.com/fulltext/java/2009/711-714.pdf. Acesso em: 10 set. 2017.

DIAS, F. J.; JOBIM, C. C.; SORIANI-FILHO, J. L.; BUMBIERIS-JUNIOR, V. H.; POPPI, E. C.; SANTELLO, G. A. Composição química e perdas totais de matéria seca na silagem de planta de soja. Acta Scientiarum Animal Sciences, Maringá, v. 32, n. 1, p. 19-26, 2010. Disponível em: https://doi.org/10.4025/actascianimsci.v32i1.4897. Acesso em: 10 set. 2017.

EICHELBERGER, L.; SIEWERDT, L.; SILVEIRA JÚNIOR, P. Efeitos da inclusão de níveis crescentes de forragem de soja e uso de inoculante na qualidade da silagem de milho. Revista Brasileira de Zootecnia, Viçosa, v. 26, n. 5, p. 867-874, 1997.

EVANGELISTA, A. R.; GARCIA, R.; OBEID, J. A. Consórcio milho-soja: rendimento forrageiro, qualidade e valor nutritivo das silagens. Revista da Sociedade Brasileira de Zootecnia, Viçosa, v. 20, n. 6, p. 578-584, 1991.

GEBREHANNA, M. M.; GORDON, R. J.; MADANI, A.; VANDERZAAG, A. C.; WOOD, J. D. Silage effluent management: A review. Journal of Environmental Management, London, v. 143, n. 1, p. 113-122, 2014. Disponível em: https://doi.org/10.1016/j.jenvman.2014.04.012. Acesso em: 15 set. 2017.

GEREN, H.; AVCIOGLU, R.; SOYA, H.; KIR, B. Intercropping of corn with cowpea and bean: Biomass yield and silage quality. African Journal of Biotechnology, Nairobi, v. 7, n. 22, p. 4100-4104, 2008. Disponível em: https://www.ajol.info/index.php/ajb/article/view/59525/47815. Acesso em: 07 jul. 2016. 
GOBETTI, S. T. C.; NEUMANN, M.; OLIVEIRA, M. R.; OLIBONI, R. Produção e utilização da silagem de planta inteira de soja (Glycine max) para ruminantes. Ambiência, Guarapuava, v. 7, n. 3, p. 603-616, 2011. Disponível em: https://revistas.unicentro.br/index.php/ambiencia/article/view/1300/1337. Acesso em: 07 jul. 2016. https://doi.org/10.5777/ambiencia.2011.03.02rb

GOMIDE, J. A.; ZAGO, C. P.; CRUZ, M. E.; EVANGELISTA, A.; GARCIA, R.; OBEID, J. A. Milho e sorgo em cultivos puros ou consorciados com soja para produção de silagens. Revista Brasileira de Zootecnia, Viçosa, v. 16, n. 4, p. 308-317, 1987.

HASSANAT, F.; GERVAIS, R.; JULIEN, C.; MASSÉ, D.I.; LETTAT, A.; CHOUINARD, P. Y.; PETIT, H. V.; BENCHAAR, C. Replacing alfalfa silage with corn silage in dairy cow diets: Effects on enteric methane production, ruminal fermentation, digestion, $\mathrm{N}$ balance, and milk production. Journal of Dairy Science, Lancaster, v. 96, n. 7, p. 553-4567, 2013. Disponível em: https://doi.org/10.3168/jds.2012-6480. Acesso em: 07 jul. 2016.

JAREMTCHUK, A. R.; JAREMTCHUK, C. C.; BAGLIOLI, B.; MEDRADO, M. T.; KOZLOWSKI, L. A.; COSTA, C.; MADEIRA, H. M. F. Características agronômicas e bromatológicas de vinte genótipos de milho (Zea mays L.) para silagem na região leste paranaense. Acta Scientiarum Animal Science, Maringá, v. 27, n. 2; p. 181-188, 2005. Disponível em: https://www.redalyc.org/pdf/3031/303126468015.pdf. Acesso em: 15 jul. 2016. https://doi.org/10.4025/actascianimsci.v27i2.1220

JOBIM, C. C.; NUSSIO, L. G.; REIS, R. A.; SCHMIDT, P. Avanços metodológicos na avaliação da qualidade da forragem conservada. Revista Brasileira de Zootecnia, Viçosa, v. 36, suplemento especial, p. 101-119, 2007. Disponível em: https://repositorio.unesp.br/bitstream/handle/11449/30785/S1516-

35982007001000013.pdf? sequence=1\&isAllowed=y. Acesso em: 15 jul. 2019. https://doi.org/10.1590/S151635982007001000013

LEMPP, B.; MORAIS, M. G.; SOUZA, L. C. F. Produção de milho em cultivo exclusivo ou consorciado com soja e qualidade de suas silagens. Arquivo Brasileiro de Medicina Veterinária e Zootecnia, Belo Horizonte, v. 52, n. 3, p. 243-249, 2000. Disponível em: http://dx.doi.org/10.1590/S0102-09352000000300013. Acesso em: 08 set. 2017.

LEONEL, F. P.; PEREIRA, J. C.; COSTA, M. G.; DE MARCO, P.; JÚNIOR, L. A. L.; PAULA SOUSA, D.; DA SILVA, C. J. Consórcio capim braquiária e soja, produtividade das culturas e características qualitativas das silagens. Revista Brasileira de Zootecnia, Viçosa, v. 37, n. 11, p. 2031-2040, 2008. Disponível em: https://repositorio.bc.ufg.br/xmlui/bitstream/handle/ri/12084/Artigo\%20-

$\% 20$ Fernando $\% 20 \mathrm{de} \% 20$ Paula $\% 20$ Leonel $\% 20 \% 20 \% 20-\% 202008$.pdf? sequence=5\&isAllowed=y. Acesso em: 08 set. 2019. https://doi.org/10.1590/S1516-35982008001100020

LOPES, K. S. M.; FERNANDES, J.; YOKOBATAKE, K. L. A.; LAZARINI, E.; PEREIRA NETO, A. C.; SANTOS, M. P.; COSTA, N. R.; LOPES, K. S. M.; ANDREOTTI, M. Composição bromatológica de silagens de grão úmido de soja com diferentes teores de umidade. Revista Tecnologia \& Ciência Agropecuária, João Pessoa, v. 8, n. 5, p. 51-58. 2014. Disponível em: http://revistatca.pb.gov.br/edicoes/volume-08-2014/volume8-numero-5-dezembro-2014/tca8510.pdf/view. Acesso em: 7 jul. 2016.

PAZIANI, S. F.; DUARTE, A. P.; NUSSIO, L. G.; GALLO, P. B.; BITTAR, C. M. M.; ZOPOLLATTO, M.; RECO, P. C. Características agronômicas e bromatológicas de híbridos de milho para produção de silagem.

Revista Brasileira de Zootecnia, Viçosa, v. 38, n. 3, p. 411-417, 2009. Disponível em:

http://www.scielo.br/pdf/rbz/v38n3/a02v38n3. Acesso em: 07 jul. 2016. https://doi.org/10.1590/S151635982009000300002 (conferir se esta no texto)

REZENDE, P. M.; ALCÂNTARA, H. P.; CARVALHO, E. R.; PASSOS, A. M. A.; DOURADO, M. A. F. S. Consórcio sorgo-soja. XV. Épocas de semeadura do sorgo, cultivares de soja e sistemas de corte na composição da forragem. Bioscience Journal, Uberlândia, v. 26, n. 5, p. 779-788, 2010. Disponível em:

http://www.seer.ufu.br/index.php/biosciencejournal/article/view/7200/5268. Acesso em: 07 jul. 2016. 
RIGUEIRA, J. P. S.; PEREIRA, O. G.; RIBEIRO, K. G.; GARCIA, R. CEZÁRIO, A. S. Soybean silage in the diet for beef cattle. Acta Scientiarum Animal Science, Maringá, v. 37, n. 1, p. 61-65, 2015. Disponível em: http://dx.doi.org/10.4025/actascianimsci.v37i1.25182. Acesso em: 10 jul. 2016.

https://doi.org/10.4025/actascianimsci.v37i1.25182

SANTOS, J. P.; REZENDE, P. M. D.; BOTREL, E. P.; PASSOS, A. M. D.; CARVALHO, E. D. A.; CARVALHO, E. R. Consórcio sorgo-soja. XIII. Efeito de sistemas de corte e arranjo de plantas no desempenho forrageiro do sorgo. Ciência e Agrotecnologia, Lavras, v.33, n. 2, p. 397-404, 2009. Disponível em: http://www.scielo.br/pdf/cagro/v33n2/v33n2a06.pdf. Acesso em: 07 jul. 2016.

https://doi.org/10.1590/S1413-70542009000200006

SILVA, Dirceu Jorge; QUEIROZ, Augusto Cesar. Análises de alimentos: métodos químicos e biológicos. 2.ed. Viçosa: UFV, 2002. 235 p.

SILVA, F. D. A. E.; AZEVEDO, C. D. The Assistat Software Version 7.7 and its use in the analysis of experimental data. African Journal of Agricultural Research, Nairobi, v. 11, n. 39, p. 3733-3740, 2016. Disponível em: https://pdfs.semanticscholar.org/acc6/b7007990b548e7735be7594481f3f5c56bbd.pdf. Acesso em: 17 set. 2019. https://doi.org/10.5897/AJAR2016.11522

THOMAS, E. D.; MANDEBVU, P.; BALLARD, C. S.; SNIFFEN, C. J.; CARTER, M. P.; BECK, J. Comparison of corn silage hybrids for yield, nutrient composition, in vitro digestibility, and milk yield by dairy cows. Journal of Dairy Science, Lancaster v. 84, n. 10, p. 2217-2226, 2001. Disponível em: http://dx.doi.org/10.3168/jds.S0022-0302(01)74668-1. Acesso em: 07 jul. 2016.

UNDIE, U. L.; UWAH, D. F.; ATTOE, E. E. Effect of intercropping and crop arrangement on yield and productivity of late season maize/soybean mixtures in the humid environment of South Southern Nigeria. Journal of Agricultural Science, Alberta, v. 4, n. 4, p. 37-50, 2012. Disponível em: http://dx.doi.org/10.5539/jas.v4n4p37. Acesso em: 07 jul. 2016.

VAN SOEST, Peter. Nutritional Ecology of the Ruminant. $1^{\text {a }}$ ed., New York: Cornell University Press, 1994. $374 \mathrm{p}$.

ZOPOLLATTO, M.; NUSSIO, L. G.; MARI, L. J.; SCHMIDT, P.; DUARTE, A. P.; MOURÃO, G. B. Alterações na composição morfológica em função dos estágios de maturação em cultivares de milho para produção de silagem. Revista Brasileira de Zootecnia, Viçosa, v. 38, n. 3, p. 452-461, 2009. Disponível em: http://www.scielo.br/pdf/rbz/v38n3/a08v38n3. Acesso em: 07 jul. 2016. https://doi.org/10.1590/S151635982009000300008 